\title{
Simulation of a passive ground-coupled cooling system for a room in a hot humid climate
}

\author{
J. O. Onyango \\ School of Architecture, University of Miami, USA
}

\begin{abstract}
The US government has set a target of reducing $\mathrm{CO}_{2}$ emissions by $20 \%$ below the 2005 targets by the year 2020. Literature review reveals that residential buildings contribute over $20 \%$ of the total emissions mainly used for space heating, cooling, water heating and lighting. In hot humid climates, the concern is mainly for cooling and hot water that account for over $50 \%$ of the total residential energy consumption in South Florida as pointed out by Fairey and Parker (in Updated Miscellaneous Electricity Loads and Appliance Energy Usage Profiles for Use in Home Energy ratings, the Buildings America Benchmark Procedures and Related calculations, 2011).

In hot humid climates, the indoor temperatures normally follow the outdoor temperatures very closely, making comfortable conditions difficult to achieve without the use of active systems. The maximum average ground temperatures at a depth of $1.0 \mathrm{~m}$ in South Florida $28^{\circ} \mathrm{C}$ according to Givoni (in Passive and low energy cooling of buildings, 1994) who examined the temperature profiles at $1 \mathrm{~m}$ below ground in Florida for different seasons. The work suggested that there was potential to rely on the ground as a heat sink to reduce carbon dioxide emissions. Therefore an arrangement where hot humid air is passed through the tubes buried underground could not only cool it but also dehumidify a certain amount before discharging into the building.

The paper presents a study of biomimetic strategy that uses a ground coupled air-cooling system to reduce $\mathrm{CO}_{2}$ emissions. The results are from simulation a typical residential house with an area of $178 \mathrm{~m}^{2}$ and floor to ceiling height of $2.44 \mathrm{~m}$ and is connected to $200 \mathrm{~mm}$ diameter plastic tubes buried underground. The tubes are laid in a slope to allow for any condensate to collect in a sump at
\end{abstract}


the end of each tube. The ventilation is assumed constant through use of a small extract fan on one of the windows, thus maintain the air velocity.

Keywords: ground-coupled, cooling, simulation, carbon dioxide emissions, hot-humid, Florida, biomimicry, nature.

\section{Introduction}

In the tropics, the air temperature and humidity are typically high, making the indoor environment uncomfortable. Generally, the conditions make it difficult to rely on natural ventilation as a source of cooling yet nature provides free resources that if harnessed can be used for heating or cooling of buildings. Animals have for centuries adapted their habits to ensure they live in comfortable environments. They rely on the natural thermal inertia for cooling their bodies, or maintaining low temperature swings by living underground. The work of Benyus [3] has reignited interest in attempts to mimic the work of nature in designs.

However, to fully take advantage of the free resources the ground offers, the understanding of both local climatic conditions and soil characteristics need to be considered. Examples can be seen from burrowing animals like rats in hot climates, or termite that have well ventilated mounds that would keep temperatures within comfortable range. In a study of Jerboa rat's habitat, Kirmiz [4] observed that the burrows were placed in well areas drained during rainy season, and went underground to about 1.25 to $1.75 \mathrm{~m}$ (figure 1). The temperature profile of the burrow was between $2.5^{\circ} \mathrm{C}$ and $4.5^{\circ} \mathrm{C}$ lower that the outside ambient air temperature.

His work revealed that it is possible to rely mainly on the thermal inertia of the ground to cool buildings even in a hot humid climate such as South Florida. The paper presents numerical simulation of that possibility. For those with lowincomes such as senior citizens, the costs of staying comfortable can be prohibitive.

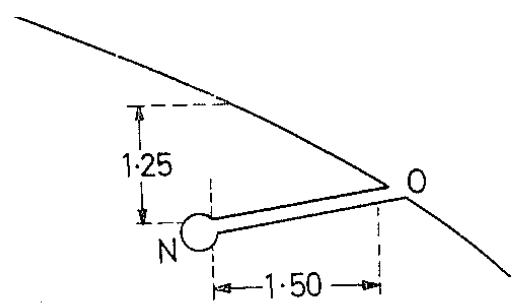

Figure 1: Jerboa Rats burrows Kirmiz [4].

\section{Thermal comfort analysis}

The ASHRAE standard on thermal comfort for human occupancy suggest that the upper limits of tolerable temperature is $26^{\circ} \mathrm{C}$. However, studies have shown that people living in the tropics can tolerate higher levels of temperature due to 
acclimatization and thus a higher standard suggested (Cowan [9]; Lovins [10]). A study of climatic data of Miami reveals that it is mostly comfortable except from months of May to October. It is thus possible to achieve indoor comfort through use of passive strategies like natural ventilation (figure 2).

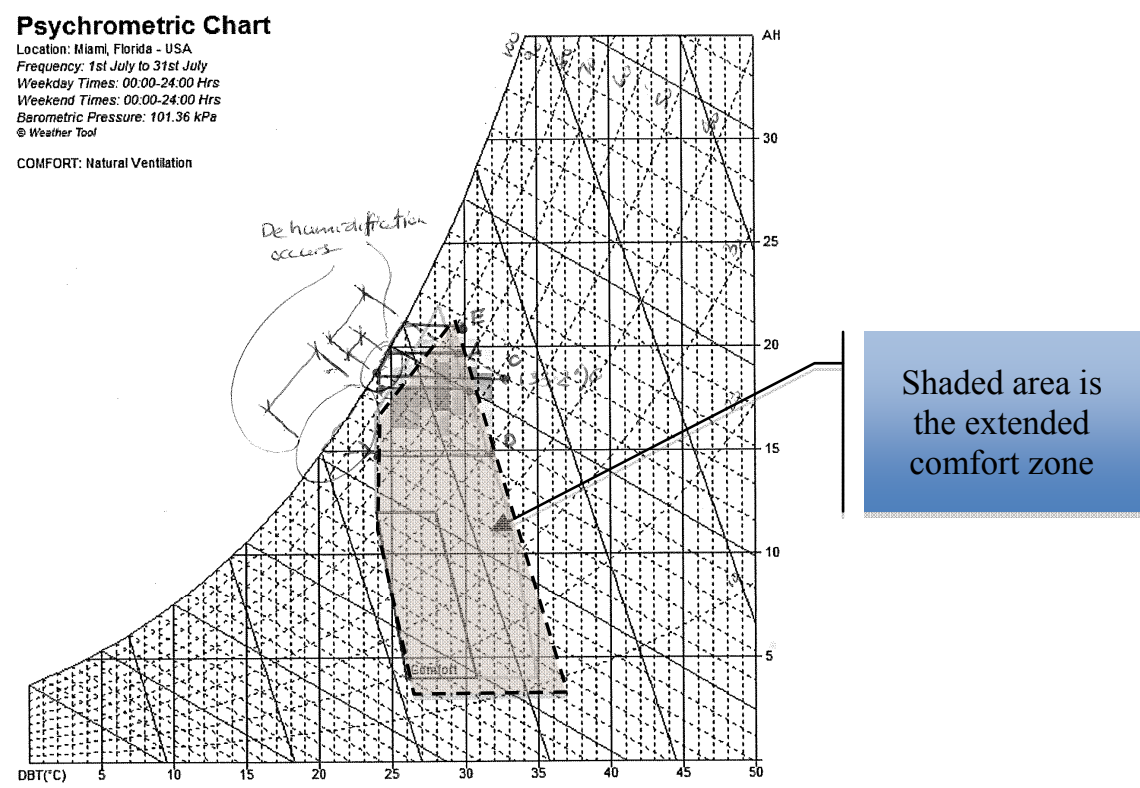

Figure 2: $\quad$ Psychometric chart Miami [has results superimposed on].

\subsection{Heat exchanger}

There are several ways in which buildings can be cooled by the earth; firstly as semi-buried objects, secondly relying on the use of earth to water heat exchangers, thirdly the use of earth to air heat exchangers and finally the use of borehole as heat exchanger. A theoretical model of soil-air heat exchangers was developed by Wang et al. [5] at the University of Nebraska and was focused on cold climates. Other attempts have been the use of radiant cooling panels in hot humid climates of Thailand by Vangtook and Chirarattanonon [6]. The radiant panel was coupled with ground source cooling. It concluded that radiant cooling could be used to achieve thermal comfort in hot and humid climate mainly by reduction in radiant temperatures.

A model that used solar chimney to assist natural ventilation for hot humid climate concluded that it was possible to achieve ambient temperature and thermal comfort in the schoolroom (Khedari et al. [7]). In addition it showed that solar assisted ventilation was more efficient than only opening of windows. Another work by Arce, J. et al. [8] examined the thermal performance on a fullscale solar chimney that revealed that it was possible to achieve average airflow rates of $177 \mathrm{~m}^{3} / \mathrm{h}$, which is sufficient for natural ventilation. 
The basic process of the heat exchanger is that as ambient air flows through the buried pipes, heat in the air is exchanged with the ground through the pipe walls and as the air emerges from the outlet where the fan is installed it is cooler than one at inlet. The mechanics are therefore heat flow and fluid dynamics equations. The ambient air temperature will typically vary throughout the day and year yet influences the earth temperature. It is assumed that the earth surrounding the pipes is homogenous and that there is little interference between the different pipes if used in parallel.

Several models exist that can be used to calculate the behavior of the earth to air heat exchanger (EAHX); Albers' model [11], for the steady air flow that examines the 3-D temperature profile; Sedlbauer's [12], a heat capacity model that takes into account the changes in air flow and Mihalakakau's et al. [13] one that relies on deterministic techniques.

The undisturbed earth temperature models have been developed; some are based on multiyear measurements (Givani and Katz [14] and Mihalakakau et al. [15]) which describe the ground temperatures at various depths. Mihalakakau et al. [16] further developed a model that considered the ambient climatic conditions. This is expressed as:

$$
T m=1 / h e[h r T m-\xi \Delta R=b S m-0.168 h s f b(1-r a)
$$

and

$$
A_{S}=\frac{\left[h_{r} A_{s a}-b S_{a} e^{(i \varphi 1-\varphi \mathrm{a})}\right]}{h e+K s o i l}
$$

where $T \mathrm{~m}$ is the mean annual ground surface temperature, $A \mathrm{~s}$ the amplitude of temperatures wave at ground surface $\left(\mathrm{C}^{\circ}\right), K$ the thermal conductivity of the soil, $\mathrm{a}=103 \mathrm{~Pa} / \mathrm{K} ; T$ ma the mean air temperature at time $2 \pi / w, w$ is the frequency of the temperature wave, $\varphi$ a the phase constant, $h$ sur $=(0.5+1.2 \sqrt{ } u)$, is the convective heat transfer coefficient at soil surface, $u$ is the wind velocity above the ground surface, $\mathrm{Sm}$ is the mean annual solar energy at ground surface, $S \mathrm{a}$ is the amplitude of solar radiation wave at $\varphi 1$ the phase constant $\left(=28 \mathrm{~W} / \mathrm{m}^{2}\right)$; $r$ a is the relative humidity of air above the ground surface, $f$ is a fraction that depends on ground cover and humidity levels ( $f=1$ for saturated soils, $0.6-0.8$ for moist soils, $0.4-0.5$ for dry soils, and 0.1-0.2 for arid soils according to Penman, [17]). Also $b$ is the coefficient that depends on ground surface absorptivity and its illumination, ( $b=1$ - albedo), They also pointed out that the thermal conductivity of the soil depended on moisture levels and in dry soils it is closer to that of air and are related as:

$$
h \mathrm{e}=h \operatorname{sur}(1+0.0168 a f) \text { and } h \mathrm{r}=h \operatorname{sur}(1+0.0168 \mathrm{araf}) .
$$

\subsection{Numerical modeling}

The heat flow between the surrounding earth and the air in the pipe is governed by the energy balance equation [6] and illustrated in figure 3 below, 


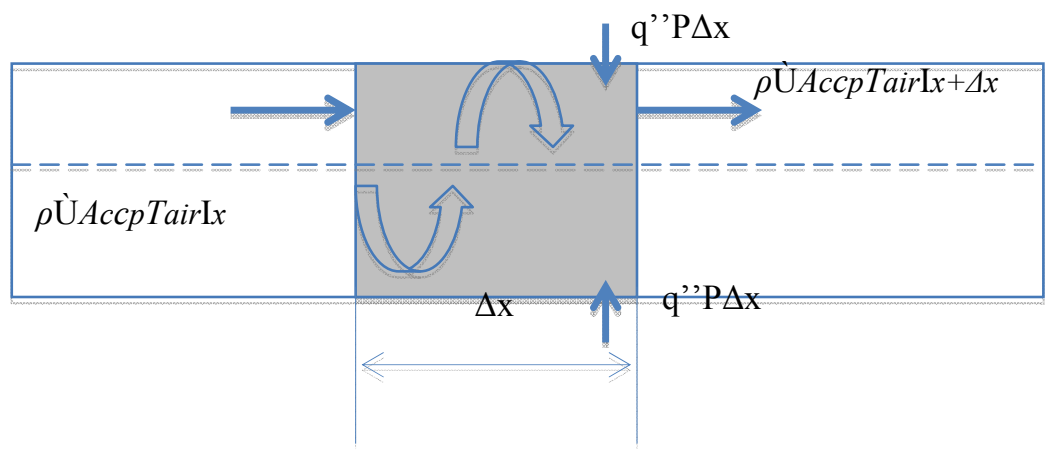

Figure 3: $\quad$ Pipe sectional view.

$$
\rho \grave{\mathrm{U} A c c p T a i r} \mathrm{I} x+\mathrm{q} ' D A c \Delta \mathrm{x}=\rho \grave{\mathrm{U} A c c p T a i r} \mathrm{I} x+\Delta x
$$

where q" is the heat transfer rate from earth to pipe, Ù is the heat transfer coefficient of air, $A \mathrm{c}$ is the cross sectional area of the pipe of diameter $D, C p$ is the specific heat capacity of the air, average velocity of the air flowing through the duct, TairI $x$ (=Tair, in) and TairI $x+\Delta x$, (=Tair, out) the average temperature of air in the duct at distance $x$ and $x+\Delta x$ respectively. The assumption in the simulation is that the ground temperature always remains constant (hence wall and earth temperatures are same) which after rearrangement and integration and substituting with values from equations (1) is written as:

$$
\text { Tair }, \text { out }=\text { Twall }+(\text { Tair }, \text { in }- \text { Twall }) e^{-\rho \mathrm{U} A c c p}
$$

The procedure for the numerical simulation method where the total length of the pipe is divided into 100 segments and the temperature behavior iterated as a series as suggested by Benkert et al. [18]. Therefore, equation (7) is applied to each of those segments, however, the total length of pipe required needs to be determined. There have also been studies that used one-dimensional analytical method to determine the physical characteristics of the EAHX, De Paepe and Janssens [19] where the equation (7) above was rearranged and used it to find a non-dimensionless group called the number of transfer units (NTU). This is dependent on the convective heat coefficient of the air in the tube, the area of heat transfer surface and the air mass flow rate. The effectiveness of the EAHX is normally selected and thus easy to decide on. It is expressed as:

$$
\varepsilon=\frac{[\text { Tair }, \text { out }- \text { Tair }, \text { earth }]}{\text { Tearth-Tair, }, \text { in }}
$$

and

$$
\varepsilon=1-e^{-h A /\left(\rho \mathrm{U} \rho \mathrm{U} A_{c} c c_{p, a i r}\right)}
$$




$$
\begin{gathered}
N T U=h A /\left(\rho \grave{\mathrm{U}} A_{c} c c_{p, \text { air }}\right) \\
\varepsilon=1-e^{-N T U}
\end{gathered}
$$

The convective heat transfer coefficient for the tubular section is however influenced by both the Nusselt $(\mathrm{Nu})$ and Reynolds numbers $(\mathrm{Re})$ as calculated by Gnielinski [20]:

$$
\begin{gathered}
N u=3.66 \text { if } R e<2300 \text { and } \\
N u=0.0214\left(R e^{0.8}-100\right) P r^{0.4} \text { If } R e \geq 2300
\end{gathered}
$$

Another parameter that is important for designing the EAHX is the pressure drop $(\Delta p)$ across the tube, which has a linear relationship with the length of the tube and the specific pressure drop $(\mathrm{J})$ that is necessary to realize a unit of the NTU and has an inverse relation with it as pointed out by De Paepe and Janssens [21].

$$
J=\Delta p / \mathrm{NTU}
$$

And the specific pressure drop $(J)$ has a relationship with the volume of airflow rate, $(V)$ which they point is governed by equation below;

$$
J=0.258\left[\frac{c_{p, a i r} \rho_{a i r}^{2} \xi}{\lambda_{\text {air }} N u D^{5}}\right] \grave{U}^{3}
$$

with $\xi=64 / R e$ if $R e<2300$ or if $R e \geq 2300 \xi=\sqrt{(1.82 \log R e-1.64)}$

Their work presented a method of determining the total length of the tubes from the $\mathbf{J}$ and NTU equations (details can be found in their paper). This is governed by the equation below which can be solved when $\varepsilon$ is assigned:

$$
L=\ln (1-\varepsilon) \sqrt[3]{[}\left[\left(c_{p, \text { air }}^{2} \rho_{\text {air }} D^{5}\right) /\left(8 \lambda_{\text {air }}^{2} \xi N u^{2}\right)\right] \sqrt[3]{J}
$$

\section{Results}

In this work, the third type of earth to air heat exchangers has been used to study as single room based on modified portable insulated office container unit $6.096 \mathrm{~m}$ long $\times 2.438 \mathrm{~m}$ wide $\times 2.438 \mathrm{~m}$ tall to be located at the university of Miami. The first container will have air-inlets on the floor and outlets on the ceiling panels of the roof as indicated in figure 4. It will also be fitted with a small fan to assist with the ventilation if needed. The design air change rate $652 \mathrm{~m}^{3} / \mathrm{h}$, that is 1.5 air change per hour, ASHRAE 62.2 [22] is based on standards acceptable for homes, site limitations for typical housing lot of $250 \mathrm{sq}$. m (limits maximum length of heat exchanger pipes to $12 \mathrm{~m}$ ); the pressure drop across the heat exchanger will be limited to no more than $100 \mathrm{~N} / \mathrm{m}^{2}$, the air ducts are $200 \mathrm{~mm}$ polyethylene pipes and a maximum efficiency of $80 \%$ for the exchanger, which is typical. 
Other data used are:

$u=3.532(\mathrm{~m} / \mathrm{s}) ; \varepsilon=80 \%$ efficiency; $c_{p, a i r}=0.024 \mathrm{~W} / \mathrm{m}^{\circ} \mathrm{K} ; \rho_{a} r=1.005 \mathrm{KJ} /$ $\mathrm{Kg} \mathrm{K} ; N u=3.66 ; \xi=\frac{64}{R e}=[0.1641] \lambda_{\text {air }}=0.0257 \mathrm{~W} / \mathrm{m}^{\circ} \mathrm{K} ; \lambda_{\text {earth }}=3.110 \mathrm{~W} / \mathrm{m}^{\circ} \mathrm{K}$; $R e=390 ; \mathrm{f}=0.7$ (moist soils); $a=103 \mathrm{~Pa} / \mathrm{K} ; b=0.75$ ([1-albedo] and albedo is 0.25 for grassy surface); $\varphi 1=0.20$ (for short grass); $S_{a}=28 \mathrm{~W} / \mathrm{m}^{2} ; A_{s}=8.1{ }^{\circ} \mathrm{C}$ (for South Florida); $K_{s}=1.56 \mathrm{~W} / \mathrm{m}^{\circ} \mathrm{C}$; $\dot{U}=652 \mathrm{~m}^{3} / \mathrm{h}$ (volume flow rate); $r_{\text {air }}=64 \%$ (Relative humidty for July), $\mathrm{Twall}=24.3^{\circ} \mathrm{C}$,

From equation (15), the total length required for the pipes is $L=-\ln (1-$ $\left.\varepsilon) \sqrt[3]{[}\left(c_{p, \text { air }}^{2} \rho_{\text {air }} D^{5}\right) /\left(8 \lambda_{\text {air }}^{2} \xi N u^{2}\right)\right] \sqrt[3]{J}$

where:

$$
\begin{gathered}
J=0.258\left[\frac{c_{p, \text { air }} \rho_{\text {air }}^{2} \xi}{\lambda_{\text {air }} N u D^{5}}\right] V^{3} \\
=\left[0.258\left(0.024^{2}\right)(1.005)(0.1641)(652)^{3} /(3.110)(3.66)(0.2)^{5}\right]=9.322 \times 10^{6}
\end{gathered}
$$

Therefore:

$$
\begin{gathered}
\left.L=-\ln (1-0.8) \sqrt[3]{[}(0.024)^{2}(1.005)(0.2)^{5}\right) / \\
\left.\left(8(0.0257)^{2}(0.1641)(3.66)^{2}\right)\right] \sqrt[3]{(9322425.17)} \\
=65.57 \mathrm{~m} .
\end{gathered}
$$

The simulation used 4 parallel pipes of $10.92 \mathrm{~m}$ or say $11.0 \mathrm{~m}$ placed at equal distance apart and connected together as indicated in figure 4.
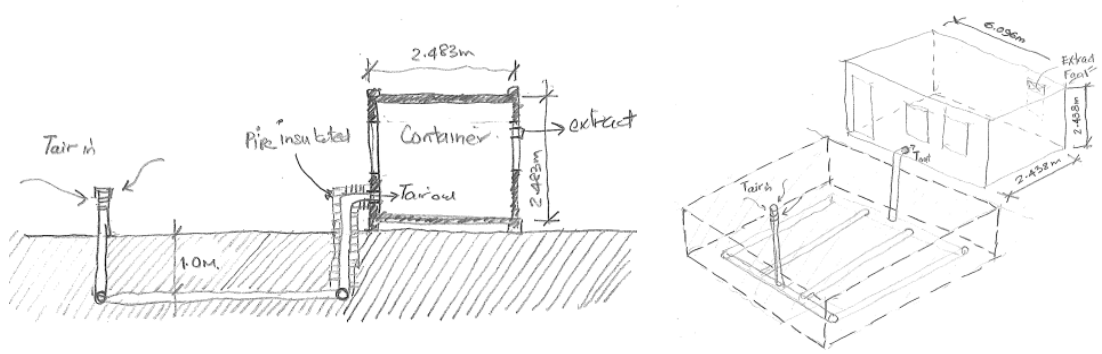

Figure 4: Arrangement of the study (schematic section and axonometric).

The results of simulation reveal that it is possible to maintain an air supply temperature to the building at $24.3^{\circ} \mathrm{C}$ which falls within the comfortable range 
for Miami in the psychometric chart. The actual temperature profile though within the room will be slightly higher due to internal heat loads from occupants and equipment. This will be studied later using experimental model. The temperature profile is similar to that of the burrowed rats at similar distance, that are lower than the ambient air temperatures by between $2.5^{\circ} \mathrm{C}$ and $4.5^{\circ} \mathrm{C}$ in the burrows and $3.8^{\circ} \mathrm{C}$ and $8.9^{\circ} \mathrm{C}$ in the simulated model of the house.

The simulation reveals that the air temperature in the tube approaches ground temperature within $12 \mathrm{~m}$, however the system has been overdesigned to accommodate reductions in wind velocity. It was however assumed in the simulation that the air speed through the pipes remained constant through use of an extract fan. It is however also possible to achieve similar results though chimney systems that can be solar activated or rely on wind pressure differential with height.

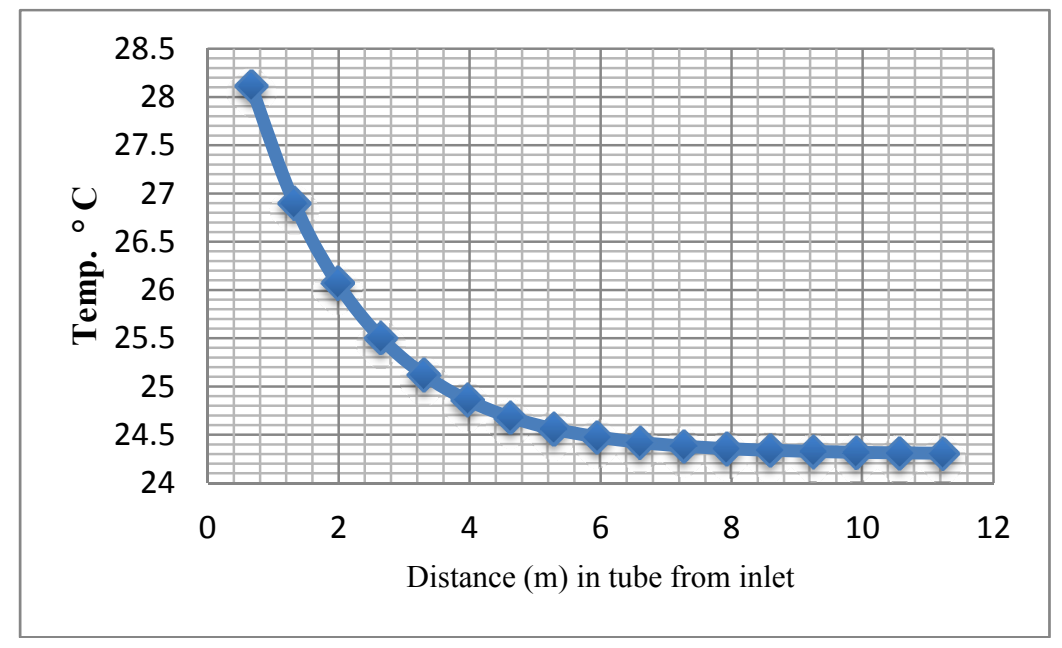

Figure 5: Profile of temperature within tubes at midnight.

Figure 7 shows the simulated data of outlet temperature as a function of inlet temperature that reveal that the EAHX performs well with a peak temperature difference of between $3.8^{\circ} \mathrm{C}$ and $8.9^{\circ} \mathrm{C}$. Figure 8 represents the temperature profile at the first slice of the 100 segments of the tube (1.98m from entry) and it reveals that there is already significant cooling achieved even this early in the pipe. 


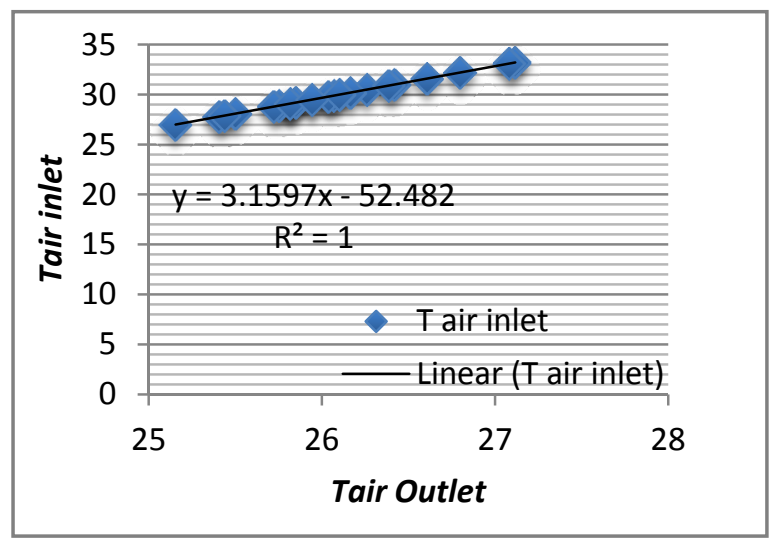

Figure 7: $\quad$ Simulated Outlet vs Inlet temperatures.

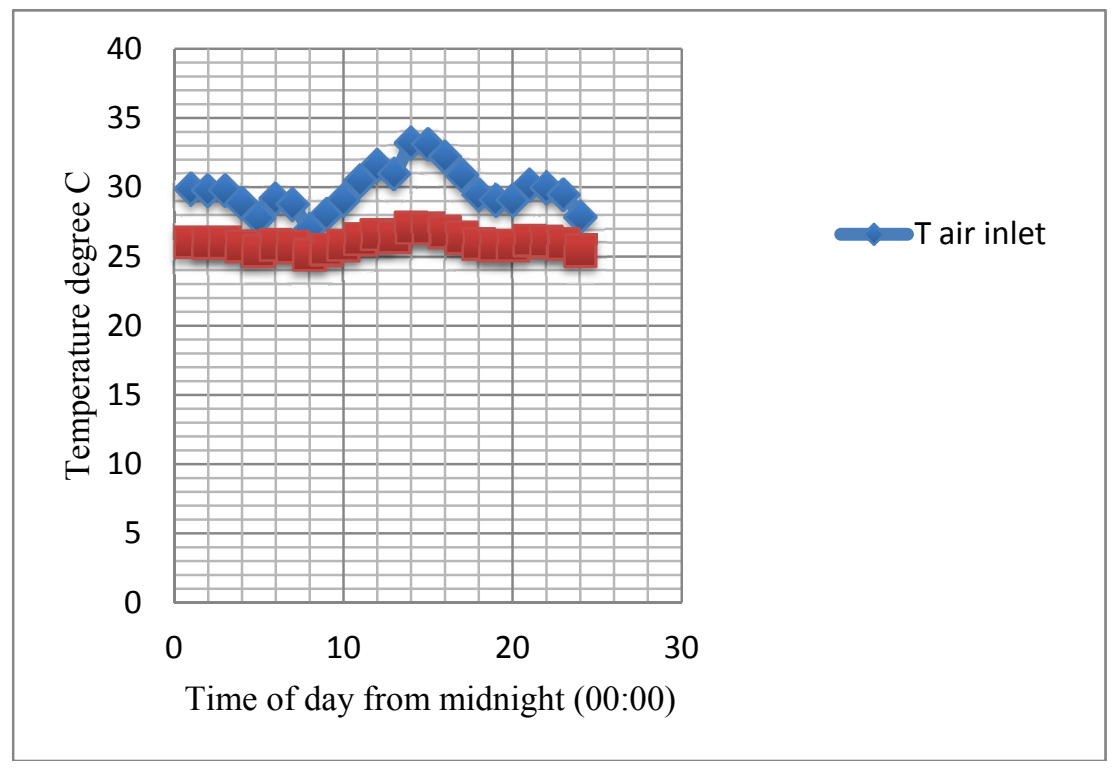

Figure 8: $\quad$ Air temperature profile in pipe at $1.98 \mathrm{~m}$ from entry.

\section{Conclusion}

The simulation study reveals that it is possible to achieve a comfortable indoor environment in hot humid climate in South Florida through the reliance on biomimicry techniques. Burrowing animals like rats have adapted well to their natural environment by living part of their life at $0.75 \mathrm{~m}$ to $1.75 \mathrm{~m}$ below the surface. The temperature in the burrows fluctuated within $2.5^{\circ} \mathrm{C}$ to $4.5^{\circ} \mathrm{C}$ below 
the ambient air temperature. Simulation results revealed similar characteristics, with the differences between $2.7^{\circ} \mathrm{C}$ and $8.9^{\circ} \mathrm{C}$ below the stifling hot climate outside. In addition the air was dehumidified as it was being cooled, thereby reducing the humidity as illustrated in the psychometric chart in figure 2 earlier. Therefore the use of biomimic passive cooling techniques can be used to bring the indoor temperature to with the extended natural ventilation comfort zone. Having deep overhangs/ eaves that would shade the walls of the buildings and reducing the heat gain through the walls can obtain further benefits.

\section{References}

[1] Fairey, P. and Parker, D. (2011). Updated Miscellaneous Electricity Loads and Appliance Energy Usage Profiles for Use in Home Energy ratings, the Buildings America Benchmark Procedures and Related calculations, Orlando, FL: Florida Energy Center, University of central Florida [available] http://www.fsec.ucf.edu/en/consumer/buildings/homes/ratings/ improve.htm [Accessed] September 19, 2011.

[2] Givoni, B. Passive and low energy cooling of buildings, New York: Van Nostrand Reinhold. 1994.

[3] Benyus, J. Biomimicry: Innovation Inspired by Nature. New York: HarperCollins Publisher Inc. 1997.

[4] Kirmiz, J. P. Adaption to Desert Environment: A study on the Jerboa Rat and Man, London: Butterworths, 1962.

[5] Wang, G.; Chen, B.; Liu, M.; Henkel, J. and Raulin, S. Analysis, Design and Preliminary Testing of Solar Chimney for Residential Air-conditioning Applications, proc. of Solar 2004: A Solar Harvest: Growing Opportunities, Portland, OR July 11-14, 2004

[6] Vangtook, P; and Chirarattananon, S. Application of radiant cooling as a passive cooling option in hot humid climate, Building and Environment, Vol. 42 (2) February 2007, pp. 543-556 [available] http://www.sciencedirect.com/science/article/pii/S0360132305004002 [accessed] February 15, 2012.

[7] Khedari, J.; Boonsri, B.; and Hirunlabh, J. Ventilation impact of a solar chimney on indoor temperature fluctuation and air change in a school building, Energy and Buildings Vol.32 pp. 89-93 2000, [Online accessed from] www.elsevier.comr locater enbuild [Accessed] February $15^{\text {th }} 2012$.

[8] Arce, J.; Jiménez, M.J.; Guzmán, J.D.; Heras, M.R.; Alvarez, G. and Xamán, J. Experimental study for natural ventilation on a solar chimney, Renewable Energy Vol. 34(12), December 2009, pp. 2928-2934 [Online accessed from] http://www.sciencedirect.com/science/article/pii/ S0960148109001931 [available] December 30, 2011.

[9] Cowan, H. J. Handbook of Architectural Technology, New York: Van Nostrond Reinhold, 1991

[10] Lovins, A., B. Air Conditioning Comfort: Behavioral and Cultural Issues, Boulder, CO: E Source Inc. 1992 
[11] Albers, J. Untersuchungen zur Auslegung von Erdw.rmeübertragern für die Konditionierung der Zuluft für Wohngebäude, Dissertation, Universität Dortmund, Dortmund 1991 (in German) quoted in Pfafferott, J. Evaluation of earth-to-air heat exchangers with a standardized method to calculate energy efficiency, Energy and Buildings, Vol. 35, pp. 971-983 [Online] available at www.sciencedirect.com

[12] Sedlbauer, K. Erdreich/Luft-Wärmetauscher zur Wohnungslüftung, Fraunhofer Institut für Bauphysik, Stuttgart, 1992 (in German) quoted in Pfafferott, J. Evaluation of earth-to-air heat exchangers with a standardized method to calculate energy efficiency, Energy and Buildings, Vol. 35, pp. 971-983 [Online] available at www.sciencedirect.com

[13] Mihalakakou, G. On the heating potential of a single buried pipe using deterministic and intelligent techniques, Renewable Energy Vol. 28, pp. 2003.

[14] Givoni, B. and Katz, L. Earth Temperatures and Underground Buildings, Energy and Buildings, Vol. 8, pp. 15-25, 1985.

[15] Mihalakakou, G., Santamouris, M., and Asimakopoulos, D. Modelling the Earth Temperature Using Multiyear Measurements, Energy and Buildings, Vol. 19(1), pp. 1-9. 1992

[16] Mihalakakou, G., Santamouris, M., Lewis, J.O., and Asimakopoulos, D.N. On the Application of the Energy Balance Equation to Predict Ground Temperature Profiles, Solar Energy, Vol. 60(3-4), pp. 181-190. 1997

[17] Penman, H. L. Vegetation and Hydrology, Farnham: Royal Commonwealth Agricultural Bureaux, 1963

[18] Benkert, St.; Heidt, F., D. and Schöler, D. Calculation Tool for EarthHeat Exchangers GAEA, Proc. Of Building Simulations, International IBPSA Conference, Prague, Vol. 2 pp. 9-16, 1997

[19] De Paepe, M. and Janssens, A. Thermo-hydraulic design of earth heat exchangers, Energy and Buildings, Vol. 35, pp. 389-397, 2003.

[20] Gnielinski, V. (1976) New equations for heat and mass transfer in turbulent pipe and channel flow, International Chemical Engineering, Vol. 16, pp. 359-368.

[21] De Paepe, M. and Janssens, A. Thermo-hydraulic design of earth heat exchangers, Energy and Buildings, Vol. 35, pp. 389-397, 2003.

[22] ASHRAE Standard 62.1, Air Leakage Performance for Detached SingleFamily Residential Buildings, American Society of Heating, Refrigerating and Air Conditioning Engineers, 2001. 